\title{
Morphometric Characterization of Indigenous Goats in East Gojjam Zone, Amhara Region, Ethiopia
}

\author{
S Getahun $^{1} \quad$ S Ahmed $^{2} \quad$ W Zemene $^{2}$ \\ 1.Department of Animal Sciences, Raya University P.O. Box: 42, Maichwe, Ethiopia \\ 2.Department of Animal Sciences, College of Agriculture and Veterinary Medicine, Jimma University, \\ P.O. Box: 307, Jimma, Ethiopia
}

\begin{abstract}
This study was conducted in HuletEjuEnesie, GonchaSisoEnesie and EnbseSarMidir districts of East Gojjam Zone with the aim to Morphometric characterize indigenous goat populations.A total of 600 goats were sampled randomly for phenotypic characterization. The most dominant coat color pattern in the sampled populations wasplain and patchy with the most frequently observed coat color type being light red, white with red and white. Sex of animal had significant effect on all of the body measurements, except ear length, chest depth, and rump length and width. EnbseSarMidir district had significantly higher body measurement values than other districts. Dentition had significant differences on body weight and most of the linear body measurements. Correlations among body weight and linear body measurements were positive for both sexes. The result of the multiple regression analysis showed that heart girth explained more variation than any other linear body measurements in both does $(71 \%)$ and bucks $(82 \%)$. The prediction of body weight could be based on regression equation $\mathrm{BW}=-$ $37.93+0.92 \mathrm{CG}$ for female sample population and $\mathrm{BW}=-44.47+1.02 \mathrm{CG}$ for male sample goat population. To sustainably utilize these goat population the production constrains should be solved and selective communitybased breeding strategies should be designed and implemented.
\end{abstract}

Keywords: Body weight, Indigenous, Linear Body Measurement, Morphometric Characterization.

DOI: $10.7176 / \mathrm{JNSR} / 12-17-03$

Publication date:September $30^{\text {th }} 2021$

\section{Introduction}

In Ethiopia, more than $85 \%$ of the human population depends on agriculture for their livelihoods (Solomon, 2014) and usually keep livestock as pastoralists or in mixed crop livestock systems. Livestock are an important section of agriculture in Ethiopia and provides milk, meat, draught power, transport, manure, hides, skins (Funk et al., 2012) and it has served as a source of income for the country (Feki, 2013).

Goats (Capra hircus) are an integral part of economic and social life especially in developing countries. Goats also can have a role in tradition, social status, social payments, rituals and ceremonies, bride price, insurance, status display, dispute compensation and as a mobile bank (Berhanu et al., 2012; Arineitwe and Ndyomugyeni, 2013).

According to CSA (2017), the number of goats reported in the country isestimated to be about 30.2 million, of which about $70.61 \%$ are females and $29.39 \%$ are males. Phenotypic characteristics are important in breed identification local genetic resources as it depends on the knowledge of the variation of morphological traits, which play very fundamental role in classification of livestock based on size and shape (Ferra et al., 2010; Agga et.al., 2010; Leng et al, 2010).

The research done so far on phenotypic characterization indicated that there are about 14 goat types in Ethiopia and Eretria (FARM Africa, 1996). In addition, there are different studies conducted in Ethiopia ,Ahmed (2013) in Horro Guduru Wollega zone Oromia region, Belete (2013) in Bale zone Oromia region, Netsanet (2014) in Meta-Robi district Oromia region and Konso district in Southern Nations, Nationalities and People's region, Bekalu (2014) in West Gojjam zone Amhara region, Alubel (2015) in north Gondar zone of Amhara region and Diba (2017) in Guji zone of Oromia region carried out to characterize the indigenous goat found in Ethiopia. However, characterization has not been done so far particularly for indigenous goats found in East Gojjam zone. FARM Africa (1996) based on the physical description study named these populations as western highland goats before two decades. According to FAO (2007) changes in population type and structure need to be documented regularly for all breeds at intervals of about five years for cattle, buffalo, sheep and goats.Goats are the major income source for farmers in East Gojjam zone. In addition, large goat populations are found in the study area. The agro ecology of the area is also suitable for goat production. Therefore, this study objective was to characterize indigenous goat populations in the study area.

\section{Materials and Methods \\ Description of the Study Area}

This study was conducted in three districts of east Gojam zone (Hulet Eju Enesie, Goncha Siso Enesie and Enbse Sar Midir) in East Gojjam zone of Amhara regional state, Ethiopia. It is $298 \mathrm{~km}$ from Addis Ababa and $265 \mathrm{~km}$ 
from the capital city Bahir Dar. The area consists of different livestock composition. According to CSA (2016/2017), the study site has 2,071,364 Cattle, 1,403,264 Sheep, 451,290 Goat, and 99,949 Horse, 425,397 Donkey, 23,999 Mules, 1,245,284 Poultry, and 181,093 Bee hives.

\section{Sampling Techniques and Sample Size Determination Sampling techniques}

A multi-stage sampling technique was employed for the selection of sample households and indigenous goats for this study. For sampling goat population, castrated goats, pregnant doe, kids, buck kids and doe kids were not included in the sample goat population to increase accuracy for quantitative traits and to represent the adult goat population.Subsequently, sample goats were taken by using simple random sampling method.

\section{Sample size determination for goats}

The sample size of indigenous goats was determined by the formula given by Cochran's (1977), totally 600 indigenous goats were used for collecting data about qualitative and quantitative traits. For physical description and quantitative traits measurement a total of 60 mature male and 540 mature female goats were used. Based on FAO (2012), from the total sample size $90 \%$ of goats were female and the remaining $10 \%$ of goats was male

\section{Data Types and Methods of Data Collection}

Secondary sources: secondary data was collected from the respective district office of livestock and Fishery resource to complement the production system along with the climatic data, agero ecology data, geographical location, and livestock demography.

\section{Morphometric characterization of indigenous goats}

The standard breed descriptor list developed for goat by FAO (2012) was closely followed in selecting qualitative and quantitative traits. Data for qualitative variables like coat color pattern, coat color type, hair type ,hair length, head profile, ear orientation, presence or absence of toggle, rump profile, back profile, beard, wattle, horn presence or absence, horn shape, horn orientation ,muzzle and ruff were recorded by visual observation of the animal goat. Quantitative trait like body weight, body length, chest girth , wither height , rump height, chest depth, canon bone length, canon bone circumference, pelvic width ,rump length ,rump width,head length,horn length, ear length were measured using plastic measuring tape. For males scrotal circumference was also measured. Body weight was measured using spring balance having 50kg capacity.

Each animal was identified by its sex, location and dentition.Goat's age classification was made using dentition.Adult goat were classified into four age group; 1PPI (one pair of permanent incisor), 2PPI (two pair of permanent incisor), 3PPI three pair of permanent incisor and $\geq 4$ PPI (four pair of permanent incisor).

\section{Data Management and Analysis}

All data gathered during the study period were coded and recorded in Microsoft Excel 2007. Then statistical data analysis used depeneds upon the nature of the data. All data were analyzed by SAS version 9.3 (2014), and SPSS version 20

Data collected through qualitative data from individual observations wereanalyzed by SPSS version 20 and chi-square test was carried out to assess the staticall significance among categorical variables using district as a fixed effect.

Quantitative data was analyzed using Statistical Analysis System (SAS Version 9.3). A general linear model procedure (PROC GLM) of the Statistical Analysis System (SAS 9.3) was used for quantitative variables to detect statistical differences among sample goat's populations. Sex, location and age group of the goats were fixed variables while body weight and linear body measurements were fitted as response variables least square means with their corresponding standard errors were calculated for each body trait over sex, age and location to test statically deference by Tukey test.

The model employed for analyses of body weight and other linear body measurements except Scrotum circumference was:

$\mathrm{Y}_{i j k l}=\mathrm{U}+\mathrm{A}_{i}+S_{j}+D_{k}+\mathrm{A} i * \mathrm{~S} j+\mathrm{e}_{i j k l l}$,Where: Yijk $l=$ the observed $k$ (body weight or linear body measurements) in the $i^{\text {th }}$ age group $\& j^{\text {th }}$ Sex, $\mathrm{U}=$ Overall mean, A $i=$ the effect of $i^{\text {th }}$ age group $(i=1,2,3, \geq 4), S j=$ the effect of $j^{\text {th }} \operatorname{Sex}(j=1$ and 2$) \mathrm{Dk}=$ the effect of $\mathrm{k}^{\text {th }}$ district (Hulet Eju Enesie, Goncha Siso Enesie and Enbse Sar Midir) $\mathrm{A}_{i} * \mathrm{~S}_{j}=$ age by sex interaction and $\mathrm{e}_{i j k l}=$ random residual error.

Live body weight and other body measurements including heart Girth , Body Length , Height at Wither , rump hight, chest depth,rump width ,Pelvic Width, horn length, cannon bone circumference ,cannon bone length,Rump Height, Rump Length, Head Length, and Ear Length were considered both for male and female goats. In addition, Scrotum Circumference was included for male.

Correlations of live body weight with different body measurement under consideration were computed for 
each sex using Pearson correlation coefficient. Stepwise regression procedure of SAS (9.3) was used to estimate body weight for both male and female using PROC REG procedure of SAS in order to determine the best-fitted regression equation for the prediction of live body weight. Best fitting models were selected based on coefficient of determination $\left(\mathrm{R}^{2}\right)$, mean square error, and the mallows $\mathrm{C}$ parameters $\mathrm{C}(\mathrm{p})$, the following models were used for the estimation of body weight from LBMs.

The following models were used for the estimation of body weight from LBMs.

For male:

$\mathrm{Y}=\beta \mathrm{o}+\beta 1 \mathrm{X} 1+\beta 2 \mathrm{X} 2+\ldots+\beta \mathrm{nX} \mathrm{n}+$ ej Where: $\mathrm{Y}=$ the response variable (body weight) $\beta \mathrm{o}=$ the intercept $\mathrm{X} 1 \ldots \mathrm{Xn}$ are the explanatory variables (height at wither, rump height, body length, chest Depth, heart girth, rump length, rump width, cannon bone length, cannon bone circumference, ear length, Horn length, pelvic width, and scrotal circumference) $\beta 1 \ldots \beta n$ are regression coefficients of the variables $\mathrm{X} 1 \ldots \mathrm{Xn}$ ej $=$ random error

\section{For female:}

$\mathrm{Y}=\beta \mathrm{o}+\beta 1 \mathrm{X} 1+\beta 2 \mathrm{X} 2+\ldots+\beta \mathrm{nX} \mathrm{n}+$ ej Where: $\mathrm{Y}=$ the dependent variable body weight; $\beta \mathrm{o}=$ the intercept; $\mathrm{X} 1, \ldots, \mathrm{Xn}$ are independent variables (height at whither, rump height, body length, chest depth, chest girth, rump length, rump width, pelvic width, cannon bone length, cannon bone circumference, head length, ear length, horn length) and rump length); $\beta 1, \ldots, \beta \mathrm{n}$ are regression coefficients of the variable $\mathrm{X} 1 \ldots, \mathrm{Xn}$

ej $=$ random error

\section{Result and Discussion \\ Morphometric Characterization of Indigenous Goats Qualitative traits}

Qualitative traits of indigenous goatspopulation in the study area are presented in Table 1. In the study area, the main dominant coat color type waslight red $(25.3 \%)$. The current variation in coat color type of indigenous goats found in the study area was different from the previous findings of FARM-Africa (1996), who reported the coat color type of western high land breed as white (42\%). Similar to this finding, in Abergelle goat red dominant coat color was observed, which accounted for 30.98\% (Alubel, 2015) and followed by red with white $(21.3 \%)$, white $(22.2 \%)$, dark red $(9.5 \%)$, brown $(5.7 \%)$, black with white $(5.5 \%)$, grey $(5 \%)$, black $(3.5 \%)$ and black and red $(2.0 \%)$ coat color type were observed in the study area .

In all study areas majority of the goat populations had no skin pigmentation (95.8\%).Smooth hair coat type was predominant in the study area, which accounted for $71.3 \%$, whereas, glossy hair coat type were $28.7 \%$ of the sampled goat population. Majority of the sampled goatshad short hair $(77.0 \%)$.

About the overall goat in all study area $(95 \%)$ of goats in the study area had horn, In contrast to this in Gurawa district occurrence of polled goat was higher than horned one (Mahilet, 2012). Straight horn shape was the most frequently observed in the study area (51.1\%) followed by curved (31.9\%), lyre/u shaped (11.2\%) and spiral (5.8\%). According to Belay and Meseretu (2017) the goats in GamoGoffa zone havepredominantly straight horn shape $(78.09 \%)$ which was higher thanwhat we observed in the current study. The overall hornorientation from the sampled goatsback ward $(86.1 \%)$ and upward $(13.9 \%)$. The most dominant ear orientationwas horizontal (76.0\%) followed by dropped $(13.0 \%)$ and lateral $(11.0 \%)$ were observed in the study area. In contrast to this finding, Hulunim (2014) reported the majority of Bati and Borena goats were characterized by lateral/sideway ear orientation accounting a total of 59.9 and $78.9 \%$, respectively.

Overall sampledgoatshad straight head profile $(72.0 \%)$, concave $(21.8 \%)$ and slightly concaves $(6.2 \%)$, this is difference with FARM-Africa (1996) reported, as a concave facial profile (100\%) in Western Highland goat. The present finding similar with the report of Yaekob (2015) in woytoGuji goat (80.6\%) have straight head profile.

Majority of goats in the study area do not have toggles $(80.2 \%)$ and beard $(76.8 \%)$. About $(71.3 \%)$ of goats in the study area has no ruff.In the study area $68.0 \%$ of sampled goats had straight back profile. Sloping rump profiles of goat types were frequently observed (96.2\%), whereas flat rump profile was observed only in $3.8 \%$ of the sampled goat population.

The chi-square test of categorical variables in HuletEjuEnesie, GonchaSisoEnesie and EnbseSarMidir sample goats population indicated that among the variables considered in this study coat color pattern, coat color type, horn shape, hair length, back profile, skin pigmentation, toggle and ruff were significantly different $(\mathrm{P}<0.05)$ across location. The most observed coat color pattern in all the study districts was plain/uniform (52.5\% in HuletEjuEnesie, 55.5\% in GonchaSisoEnesie and $48.0 \%$ in EnbseSarMidir). In the study area, the main dominant coat color type waslight red $(25.3 \%)$. The current variation in coat color type of indigenous goats found in the study area was different from the previous findings of FARM-Africa (1996), who reported the coat color type of western high land breed as white $(42 \%)$. highest plain coat color pattern were recorded in GonchaSisoEnesie and lowest recorded inEnbseSarMidir. On the other hand, patchy coat color pattern was frequently observed in EnbseSarMidir (36.0\%) and GonchaSisoEnesie (35.6\%) district than in HuletEjuEnesie district (31.1\%). 
The dominant coat color types in HuletEjuEnesie district were white $(42.0 \%)$ and red and white $(14.0 \%)$ whereas in GonchaSisoEnesie district, the dominant coat color types were light Red (33\%) and Red +white $(22 \%)$. In EnbseSarMidir district, light red (33\%) and red +white $(28.0 \%)$ were frequently occurred coat color types.

In EnbseSarMidir district highest number of goats had predominatlyshort hair $(85.5 \%)$ than GonchaSisoEnse 974.0\%) and Enbse Sar Midir(71.1\%) district.

In EnbseSarMidir higher pigmented than HuletEjuEnesie and GonchaSisoEnesie. The highest proportion of goat populations had horn inGonchaSisoEnesie99\% than Hulet Eju Enesie(93.9\%)and EnbseSarMidir (97.8\%).In HuletEjuEnesie, 53.3\% of goats had straighthorn shapeand also in GonchaSisoEnesie straight horn shape but in EnbseSarMidirdistinctcurved horn shape was (50.55\%).

The presence of ruff higher in HuletEju Enesie (34.5\%) than in GonchaSisoEnesie (30.5\%) and in Enbse SarMidir (21\%). In Hulet Eju Enesie (22.2\%) higher in toggle presence than GonchaSiso Enesie (15.3\%) and EnbseSarMidir (15.55\%).

Table 1.Qualitative traits of goats in the study area by sex and district

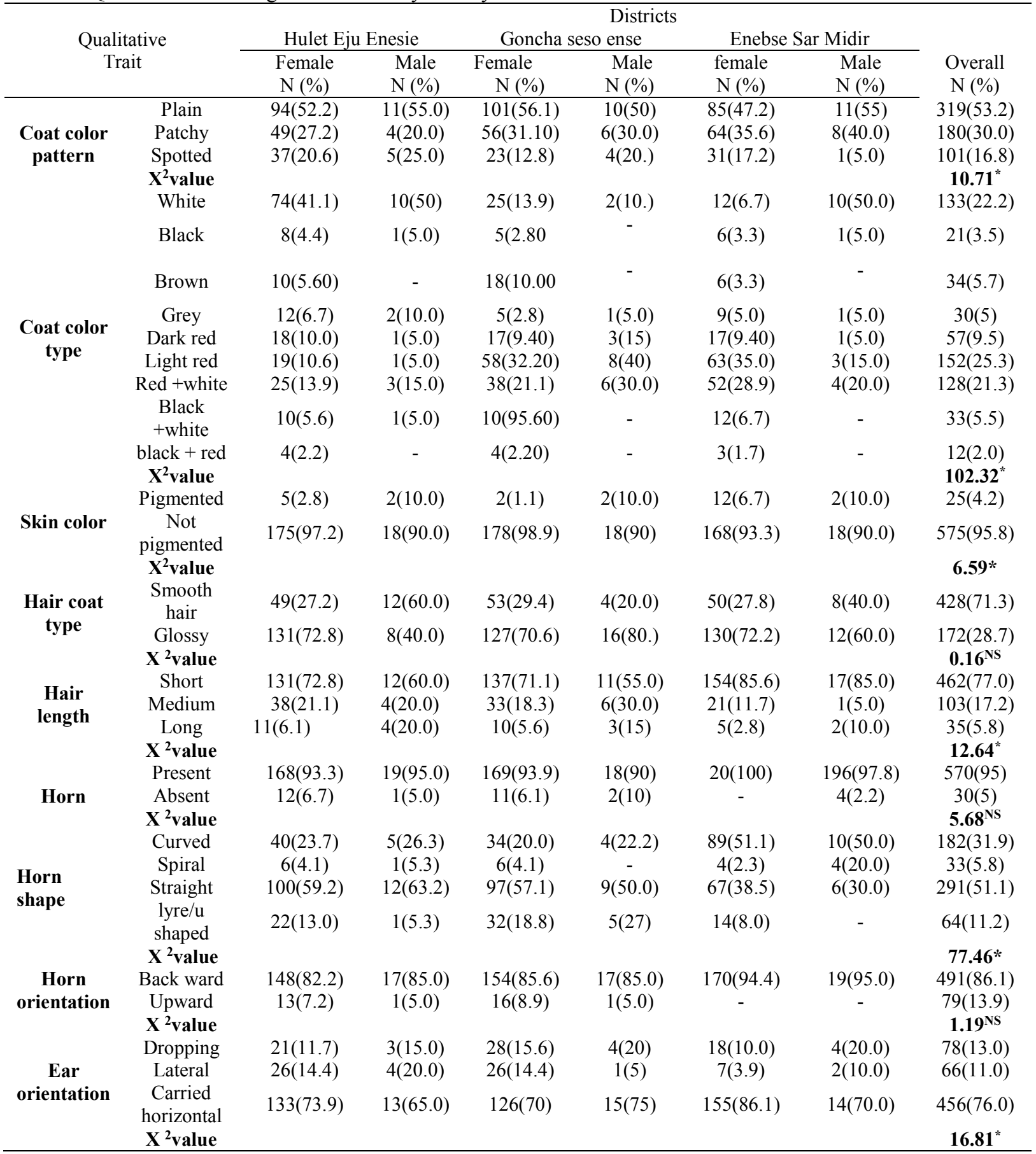




\begin{tabular}{|c|c|c|c|c|c|c|c|c|}
\hline \multirow{4}{*}{$\begin{array}{l}\text { Facial } \\
\text { profile }\end{array}$} & Straight & $135(75.0)$ & $16(80.0)$ & $130(72.2)$ & $12(60.0)$ & $124(68.9)$ & $15(75.0)$ & $432(72.0)$ \\
\hline & Concave & $29(16.1)$ & $4(20.0)$ & $40(22.2)$ & $5(25.0)$ & $48(26.7)$ & $5(25.0)$ & $131(21.8)$ \\
\hline & Convex & $16(8.9)$ & - & $10(5.6)$ & $3(15.0)$ & $8(4.4)$ & - & $37(6.2)$ \\
\hline & $\begin{array}{l}\text { slightly } \\
\text { concave }\end{array}$ & - & - & - & - & - & - & \\
\hline \multirow{3}{*}{ Beard } & $\mathbf{X}^{2}$ value & & & & & & & $7.8^{\mathrm{NS}}$ \\
\hline & Present & $44(24.4)$ & $7(35.0)$ & $35(19.4)$ & $5(25.0)$ & 42)23.3) & $6(30.0)$ & $139(23.2)$ \\
\hline & $\begin{array}{c}\text { Absent } \\
\mathbf{X}^{2} \text { value }\end{array}$ & $136(75.6)$ & $13(65.0)$ & $145(80.6)$ & $15(75.0)$ & $138(76.7)$ & $14(70.0)$ & $\begin{array}{c}461(76.8) \\
\mathbf{1 . 8 1}^{\text {NS }}\end{array}$ \\
\hline \multirow{2}{*}{ Ruff } & Present & $59(32.8)$ & $10(50.0)$ & $57(31.7)$ & $16(80.0)$ & $38(21.1)$ & $4(20.0)$ & $172(28.7)$ \\
\hline & Absent & $121(67.2)$ & $10(50.0)$ & $123(68.3)$ & $4(20.0)$ & $142(78.9)$ & $16(80.0)$ & $428(71.3)$ \\
\hline \multirow{3}{*}{$\begin{array}{c}\text { Back } \\
\text { profile }\end{array}$} & $\begin{array}{l}\text { Slops up to } \\
\text { rump }\end{array}$ & $55(30.6)$ & $6(30.0)$ & $76(42.2)$ & $9(45.0)$ & $39(21.7)$ & $2(10.0)$ & $187(31.2)$ \\
\hline & $\begin{array}{l}\text { Slops up to } \\
\text { the wither }\end{array}$ & $125(69.4)$ & $14(70.0)$ & $102(56.7)$ & $10(50.0)$ & $139(77.2)$ & $18(90.0)$ & $408(68.0)$ \\
\hline & & - & - & $2(1.1)$ & $1(5.0)$ & $2(1.1)$ & - & $5(0.8)$ \\
\hline \multirow{3}{*}{$\begin{array}{l}\text { Rump } \\
\text { profile }\end{array}$} & $X^{2}$ value & & & & & & & $25.91^{*}$ \\
\hline & Sloping & $173(96.1)$ & $17(85.0)$ & $172(95.6)$ & $18(90)$ & $177(98.3)$ & $20(100)$ & $577(96.2)$ \\
\hline & $\begin{array}{c}\text { Flat } \\
\mathbf{X}^{2} \text { value }\end{array}$ & $7(3.90$ & $3(15)$ & $8(4.4)$ & $2(10)$ & $3(1.7)$ & - & $\begin{array}{c}23(3.8) \\
\mathbf{4 . 4 3}^{\mathrm{NS}}\end{array}$ \\
\hline \multirow{2}{*}{ Toggle } & Present & $53(29.4)$ & $3(15.0)$ & $37(20.6)$ & $2(10)$ & $20(11.1)$ & $4(20)$ & $119(19.8)$ \\
\hline & Absent & $127(70.6)$ & $17(85)$ & $143(79.4)$ & $18(90)$ & $\begin{array}{c}160(88.9) \\
16.12^{*}\end{array}$ & $16(80)$ & $481(80.2)$ \\
\hline \multirow{2}{*}{ Wattle } & Present & $14(7.8)$ & $2(10)$ & $22(12.2)$ & $3(15.0)$ & $17(9.40)$ & $4(20.00)$ & $62(10.3)$ \\
\hline & Absent & $166(92.2)$ & $18(90)$ & $158(88.8)$ & $17(85)$ & $163(90.6)$ & $16(80.0)$ & $538(89.7)$ \\
\hline$X^{2}$ value & & & & & & & & $2.19^{\mathrm{N} S}$ \\
\hline
\end{tabular}

$\mathrm{N}=$ Number of goat exhibiting a particular qualitative character; $\mathrm{X}^{2}=$ Pearson chi-square;;*significant difference at $\mathrm{p}<0.05 ; \mathrm{NS}=$ Non-Signific

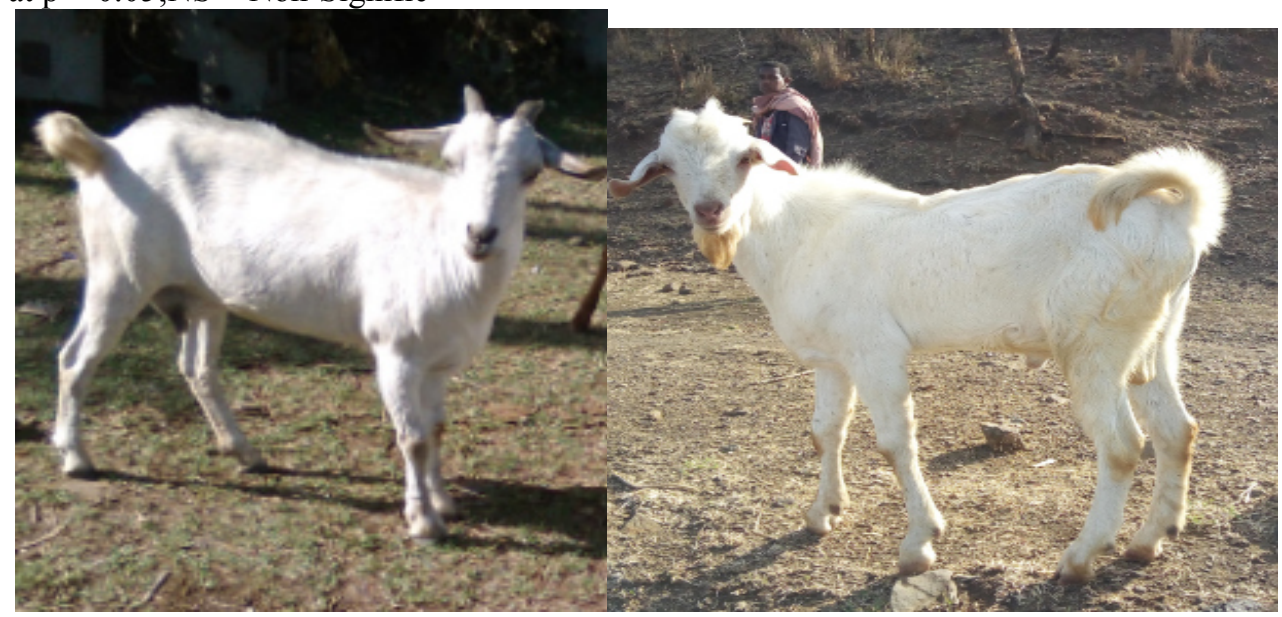

Figure 1. Adult indigenous breeding doe (left) and Buck (right) in Hulet Eju Enesie district

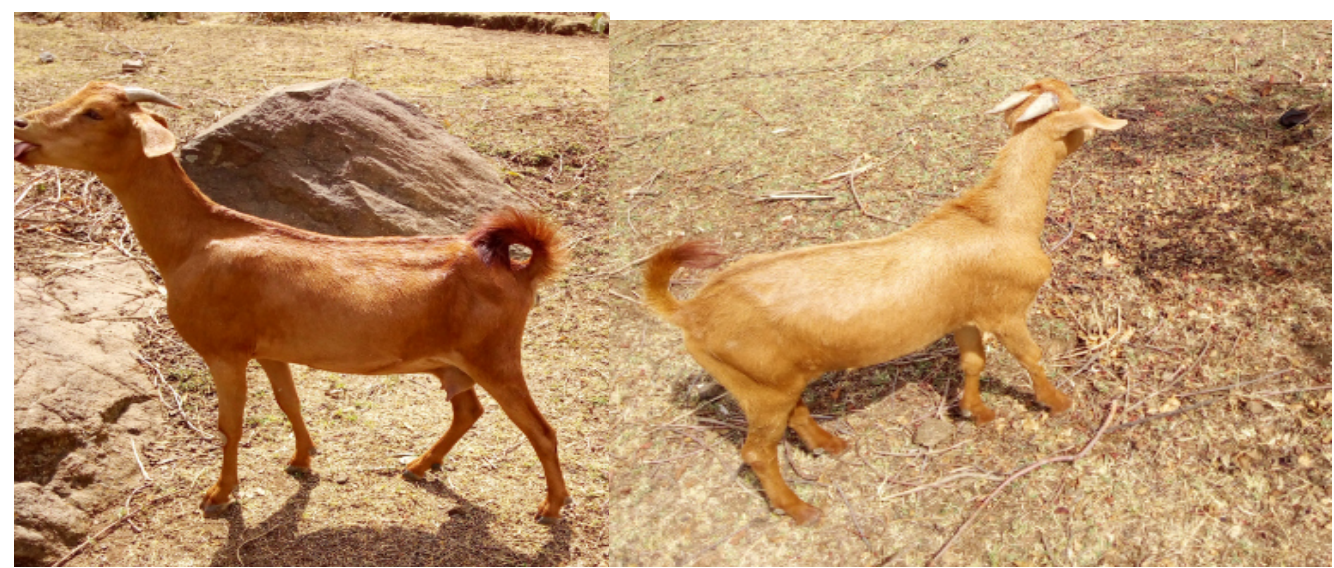

Figure 2. Adult indigenous breeding doe (left) and buck (right) in Goncha Siso Enesie district 


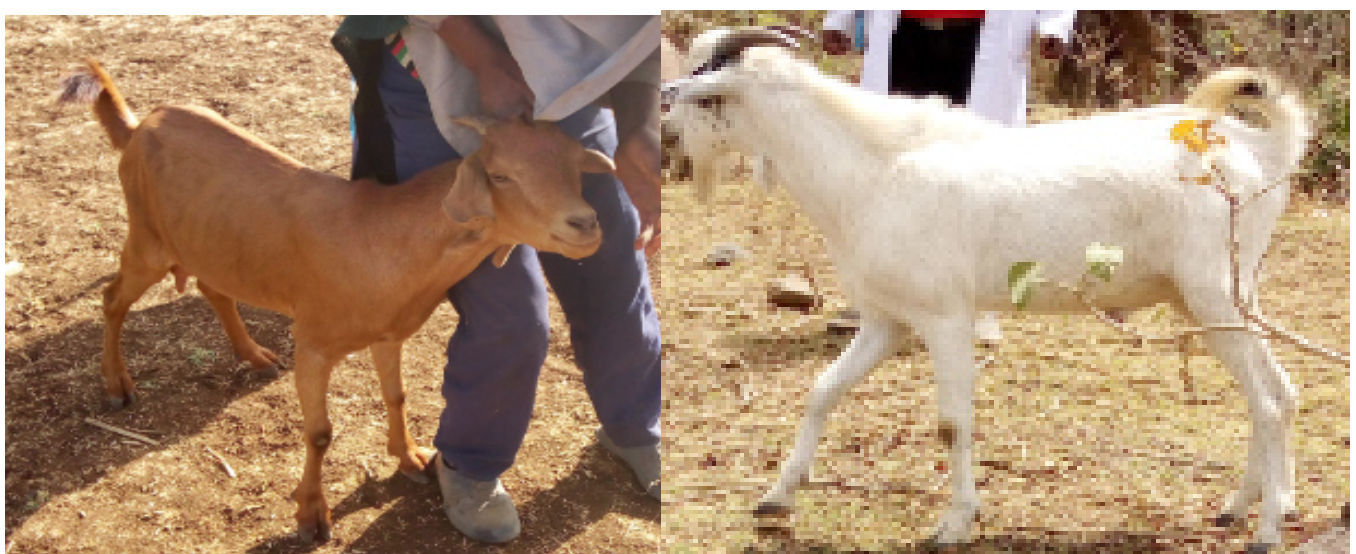

Figure 3. Adult indigenous breeding doe (left) and buck (right) in Enbse Sar Midir district

\section{Quantitative traits of indigenous goats}

Body weight and liner body measurements are the most important characters, which help to identify the breeds of goat population. The body weight and linear body measurements of indigenous goat in the study area are presented in Table 2.

In the study area overall mean of body weight, body length, chest girth, height at withers ,pelvic width, rump height, rump length, rump width, head Length, ear length, horn length, chest depth, canone bone circumference, canone bone length and scrotum circumference were $29.05 \mathrm{~kg}, 61.94 \mathrm{~cm}, 72.16 \mathrm{~cm}, 66.77 \mathrm{~cm}$, $9.30 \mathrm{~cm}, 68.89 \mathrm{~cm}, 14.62 \mathrm{~cm}, 15.64 \mathrm{~cm}, 14.45 \mathrm{~cm}, 14.33 \mathrm{~cm}, 10.57 \mathrm{~cm}, 29.28 \mathrm{~cm}, 8.46 \mathrm{~cm}, 12.29 \mathrm{~cm}$, and $22.73 \mathrm{~cm}$, respectively. The Result was comparable with Ahmed (2013); Bekalu, (2014) and Diba (2017) indicates that the Average body weight, body length, chest girth, height at withers and ear length were $28.7 \mathrm{~kg}, 56.9 \mathrm{~cm}, 70.8 \mathrm{~cm}$, $67.2 \mathrm{~cm}$ and $14.9 \mathrm{~cm}$ for western highland goat in Horro Gudru Welega, $28.03 \mathrm{~kg}, 60.19 \mathrm{~cm}, 74.87 \mathrm{~cm}, 64.51$ $\mathrm{cm}$,and $13.89 \mathrm{~cm}$ for western highland goat in west gojjam, $29.7 \mathrm{~kg}, 63.2 \mathrm{~cm}, 73.4 \mathrm{~cm}, 67.3$ and $17 \mathrm{~cm}$ for Woyito Guji goat in Guji zone oromia region, respectively.

Location effect: Location had significant difference $(\mathrm{P}<0.05)$ for all quantitative traits except horn length and canone bone circumference.Lower values were observed in allinear body measurements for Hulet Eju Enesie compared to Enbse Sar Midir and Goncha Siso Enesie districts except scrotum circumference and horn length Table 2. The results of this study revealed that body weight was higher for Enbse Sar Midir (31.15BW) than Hulet Eju Enesie (27.67BW) and Goncha Siso Enesie (29.67BW) districts. This might be explained by different factors such as nutrition, shortage of grazing areas in the site could be implicated, farming system is depend on extensive grazing without supplementation, the incidence of disease, the size and productivity of the grazing land can be taken as the main factors affecting livestock productivity in the study area.Similar to this finding differences in genetic makeup of the animal, availability of feed resource base (in terms of quantity and quality), availability of natural grazing field and the management conditions the animals (Cam et al., 2010).

The effect of Sex: sex is an important source of variation for live body weight and linear body measurements at all age groups. In all three districts sex had significant effect $(\mathrm{P}<0.05)$ on body weight, body length, chest girth, height at wither, rump height, cannon bone circumference, head length, cannon bone length, horn length and pelvic width, whereas chest depth, ear length, rump length and rump width were not affected by sex.Male goats were having higher values than femalesthe sex related differences might be partly a function of the sex differential hormonal effect on growth. In addition to that, the differentials obtained in the morphological traits of the sexes could be attributed to sexual dimorphism (Semakula, 2010). They also suggested that males might have a longer season of mass gain each year throughout their lives, while females divert annual resources into reproduction, rather than body mass.

Age effect: -All body measurements increased as age group increased from 1PPI to $\geq 4 \mathrm{PPI}$. In the current study body weight $(\mathrm{BW})$ had significant difference $(\mathrm{P}<0.05)$ in all age (dentition) groups and the same was true for all linear body measurements. The body weight of goats at $\geq 4 \mathrm{PPI}$ was $33.49 \pm 0.43 \mathrm{~kg}$, which is lower than $36.4 \pm 0.8$ $\mathrm{kg}$ reported for indigenous goats in Horro Guduru Wollega (Ahmed, 2013). The linear body measurements increased as animal advances with age (1PPI to $\geq 4 \mathrm{PPI}$ ). Increased with increase in dentition class up to the four Dentition and then after it starts to decline or remains as it is. The size and shape of the animal increases until the animal reaches its optimum growth point or until maturity (Yoseph, 2007).

The interaction effect of Sex and age: - The interaction of sex and age group was significant $(p<0.05)$ for body weight, Body length, chest girth, rumpwidth, pelvic width and rumpheight, wither height. The interaction effect Sex and agesignificantly difference ( $p>0.05)$ were not observed in ear length, rump length, chest depth, canone bone circumference, head length, canone bone length and horn length. Contrary to this, Alefe (2014) reported 
that the interaction of sex and age group was significant difference $(\mathrm{p}<0.05)$ all liner body measurements. In each age group males were having higher values. The value of body weight for female goat in age group 1PPI, 2PPI, 3PPI and > 4PPI were kg, $23.11 \mathrm{~kg}, 26.51 \mathrm{~kg}, 29.85 \mathrm{~kg}$ and $32.06 \mathrm{~kg}$, respectively and the values for males in the same age groups were $26.88 \mathrm{~kg}, 29.25 \mathrm{~kg}, 31.00 \mathrm{~kg}$ and $35.00 \mathrm{~kg}$, respectively. Higher body weight of males than that of females at all ages is attributed to aggressive behavior of males during feeding and sucking and male sex hormone, which has an anabolic effect. In all age groups and measurements, male goats performed greater than female goats. This finding was in agreement with short eared Somali goats and Hararghe Highland goats, where values for male goats were found greater than their female counter parts in all age group and all measurements (Grum, 2010; Mahilet, 2012).but in contrast with the report of Alade et al. (2008); Sowande et al. (2009); Samakulaet al. (2010); and Okbeku et al. (2011) were female have higher body weight and other body measurements than male counterpart.

Table 2. (Least square mean $\pm \mathrm{SE}$ ) body weight $(\mathrm{kg})$ and other linear body measurements by sex, age and location.

\begin{tabular}{|c|c|c|c|c|c|c|c|c|c|c|c|c|}
\hline Effect level & CG & $\mathrm{BL}$ & $\mathrm{WH}$ & RH & PW & EL & RL & CBL & CBC & $\mathrm{RW}$ & BW & Sc \\
\hline & $\mathrm{LSM} \pm \mathrm{SE}$ & $\mathrm{LSM} \pm \mathrm{SE}$ & $\mathrm{LSM} \pm \mathrm{SE}$ & $\mathrm{LSM} \pm \mathrm{SE}$ & $\mathrm{LSM} \pm \mathrm{SE}$ & $\mathrm{LSM} \pm \mathrm{SE}$ & $\mathrm{LSM} \pm \mathrm{SE}$ & $\mathrm{LSM} \pm \mathrm{SE}$ & $\mathrm{LSM} \pm \mathrm{SE}$ & $\mathrm{LSM} \pm \mathrm{SE}$ & $\mathrm{LSM} \pm \mathrm{SE}$ & LSM \pm SE \\
\hline Overall & $72.2 \pm 0.2$ & $61.9 \pm 0.24$ & $66.7 \pm 0.22$ & $68.89 \pm 0.20$ & $9.3 \pm 0.0$ & $14.3 \pm 0.0$ & $14.6 \pm 0.0$ & $12.2 \pm 0.06$ & $8.4 \pm 0.0$ & $15.6 \pm 0.0$ & $29.0 \pm 0.2$ & $22.7 \pm 0.3$ \\
\hline $\mathrm{CV} \%$ & 6.4 & 7.23 & 6.4 & 5.98 & 16.1 & 10.4 & 11.3 & 11.8 & 11.6 & 12.0 & 18.0 & 5.9 \\
\hline $\mathrm{R}^{2}$ & 0.4 & 0.42 & 0.3 & 0.35 & 0.3 & 0.2 & 0.5 & 0.2 & 0.1 & 0.2 & 0.3 & 0.4 \\
\hline Sex & $*$ & $*$ & $*$ & * & $*$ & NS & NS & & . & NS &  & \\
\hline Male & $73.8^{\mathrm{a}} \pm 0.6$ & $63.10^{a} \pm 0.59$ & $68.3^{\mathrm{a}} \pm 0.5$ & $70.2^{\mathrm{a}} \pm 0.5$ & $10.6^{a} \pm 0.2$ & $14.1 \pm 0.1$ & $14.8 \pm 0.2$ & $12.8^{\mathrm{a}} \pm 0.1$ & $9.4^{a} \pm 0.1$ & $15.7 \pm 0.2$ & $31.1^{a} \pm 0.6$ & $22.7 \pm 0.3$ \\
\hline Female & $70.9^{\mathrm{b}} \pm 0.2$ & $60.82^{b} \pm 0.22$ & $65.8^{b} \pm 0.2$ & $68.0^{\mathrm{b}} \pm 0.2$ & $8.9^{b} \pm 0.0$ & $14.1 \pm 0.0$ & $14.2 \pm 0.0$ & $12.1^{b} \pm 0.0$ & $8.2^{\mathrm{b}} \pm 0.0$ & $15.3 \pm 0.0$ & $27.8^{b} \pm 0.2$ & NA \\
\hline Age & & & * & & $*$ & * & $*$ & $*$ & * & $*$ & & \\
\hline 1PPI & $68.3^{c} \pm 0.4$ & $57.97^{\circ} \pm 0.41$ & $63.3^{\mathrm{c}} \pm 0.4$ & $65.5^{\mathrm{c}} \pm 0.3$ & $8.7^{b} \pm 0.1$ & $13.2^{x^{ \pm}} \pm 0.1$ & $12.3^{\mathrm{c}} \pm 0.1$ & $11.3^{b} \pm 0.1$ & $8.4^{\mathrm{b}} \pm 0.0$ & $14.5^{b} \pm 0.1$ & $25.2^{c} \pm 0.4$ & $21.4^{c} \pm 0.2$ \\
\hline 2PPI & $70.3^{\mathrm{bc}} \pm 0.5$ & $60.01^{\mathrm{bc}} \pm 0.54$ & $65.8^{\mathrm{bc}} \pm 0.5$ & $67.9^{\mathrm{bc}} \pm 0.5$ & $9.6^{b} \pm 0.1$ & $13.8^{\mathrm{bc}} \pm 0.1$ & $13.8^{\mathrm{bc}} \pm 0.2$ & $12.6^{\mathrm{a}} \pm 0.1$ & $8.8^{\mathrm{ab}} \pm 0.1$ & $15.2^{\mathrm{ab}} \pm 0.2$ & $27.9^{\mathrm{bc}} \pm 0.6$ & $22.5^{\mathrm{b} \pm} \pm 0.7$ \\
\hline 3PPI & $74.1^{\mathrm{ab}} \pm 0.6$ & $63.79^{\mathrm{b}} \pm 0.61$ & $68.8^{\mathrm{b}} \pm 0.5$ & $70.8^{\mathrm{ab}} \pm 0.5$ & $10.1^{b} \pm 0.2$ & $14.5^{\mathrm{b}} \pm 0.2$ & $15.6^{\mathrm{b}} \pm 0$ & $12.8^{\mathrm{a}} \pm 0.2$ & $8.99^{\mathrm{ab}} \pm 0.1$ & $15.6^{a} \pm 0.2$ & $31.2^{b} \pm 0.7$ & $22.9^{\mathrm{ab}} \pm 0.5$ \\
\hline 4PPI & $76.6^{a} \pm 0.3$ & $66.06^{a} \pm 0.36$ & $70.5^{a} \pm 0.3$ & $72.2^{2} \pm 0.3$ & $10.6^{a} \pm 0.1$ & $14.9^{a} \pm 0.1$ & $16.2^{\mathrm{a}} \pm 0.1$ & $13.2^{\mathrm{a} \pm 0.1}$ & $9.2^{a} \pm 0.0$ & $16.6^{\mathrm{a} \pm 0.1}$ & $33.4^{a} \pm 0.4$ & $24.1^{\mathrm{a} \pm 0.2}$ \\
\hline Location & * & $*$ & $*$ & $*$ & $*$ & $*$ & $*$ & $*$ & NS & $*$ & $*$ & $*$ \\
\hline $\begin{array}{l}\text { Hulet Eju } \\
\text { Enesie }\end{array}$ & $71.6^{6} \pm 0.4$ & $60.51^{\circ} \pm 0.42$ & $66.02^{\mathrm{c}} \pm 0.4$ & $68.4^{c} \pm 0.3$ & $9.3^{\mathrm{c}} \pm 0.1$ & $13.8^{\mathrm{b}} \pm 0.1$ & $14.3^{b} \pm 0.1$ & $11.9^{b} \pm 0.1$ & $8.8 \pm 0.0$ & $15.1^{\circ} \pm 0.1$ & $27.6^{\circ} \pm 0.4$ & $23.3^{\mathrm{a}} \pm 0.3$ \\
\hline $\begin{array}{l}\text { Goncha Siso } \\
\text { Enesie }\end{array}$ & $71.9^{b} \pm 0.4$ & $62.35^{b} \pm 0.41$ & $67.4^{\mathrm{b}} \pm 0.4$ & $69.2^{b} \pm 0.3$ & $9.8^{b} \pm 0.1$ & $14.0^{\mathrm{b}} \pm 0.1$ & $14.3^{b} \pm 0.1$ & $12.8^{\mathrm{a}} \pm 0.1$ & $8.8 \pm 0.0$ & $15.5^{\mathrm{b}} \pm 0.1$ & $29.6^{b} \pm 0.4$ & $22.2^{\mathrm{b}} \pm 0.3$ \\
\hline $\begin{array}{l}\text { Enebse Sar } \\
\text { Midir }\end{array}$ & $73.4^{4 a t} 0.4$ & $63.01^{a} \pm 0.41$ & $67.9^{\mathrm{a}} \pm 0.4$ & $69.8^{\mathrm{a}} \pm 0.3$ & $10.2^{a} \pm 0.1$ & $14.6^{a} \pm 0.1$ & $14.9^{\mathrm{a}} \pm 0.1$ & $12.6^{\mathrm{a}} \pm 0.1$ & $8.9 \pm 0.0$ & $15.8^{\mathrm{a}} \pm 0.1$ & $31.1^{a} \pm 0.4$ & $22.6^{\mathrm{ab}} \pm 0.3$ \\
\hline Sex by age & * & * & * & * & * & NS & NS & NS & & * & ${ }^{*}$ & $\mathrm{NA}$ \\
\hline Female, 1PPI & $66.4^{\circ} \pm 0.4$ & $56.29^{c} \pm 0.40$ & $61.7^{\mathrm{d}} \pm 0.3$ & $64.2^{\mathrm{c}} \pm 0.3$ & $7.9^{c} \pm 0.1$ & $13.2 \pm 0.1$ & $12.0 \pm 0.1$ & $10.8 \pm 0.1$ & $7.9 \pm 0.0$ & $14.1^{\circ} \pm 0.1$ & $23.1^{d} \pm 0.4$ & $\mathrm{NA}$ \\
\hline Female,2PPI & 70. $1^{\mathrm{bc}} \pm 0.9$ & $59.73^{\mathrm{bc}} \pm 0.90$ & $64.3^{\mathrm{cd}} \pm 0.8$ & $66.3^{\mathrm{bc}} \pm 0.8$ & $9.0^{\mathrm{b}} \pm 0.3$ & $13.9 \pm 0.1$ & $13.6 \pm 0.1$ & $12.3 \pm 0.1$ & $8.2 \pm 0.1$ & $14.8^{b c} \pm 0.3$ & $26.5^{\mathrm{cd}} \pm 0.5$ & $\mathrm{NA}$ \\
\hline Female,3PPI & $68.9^{\circ} \pm 0.5$ & $59.00^{\mathrm{bc}} \pm 0.49$ & $64.6^{\mathrm{sd}} \pm 0.47$ & $66.9^{\mathrm{bc}} \pm 0.4$ & $8.8^{\mathrm{bc}} \pm 0.1$ & $14.6 \pm 0.1$ & $15.3 \pm 0.2$ & $12.3 \pm 0.1$ & $8.3 \pm 0.1$ & $15.0^{b c} \pm 0.2$ & $29.8^{b c d} \pm 0.7$ & NA \\
\hline Female,4PPI & $72.5^{\mathrm{abc}} \pm 2$ & $60.50^{\mathrm{abc}} \pm 2.2$ & $65.5^{\text {abd }} \pm 2.1$ & $67.2^{\mathrm{bc}} \pm 2.0$ & $10.2^{b} \pm 0.7$ & $14.8 \pm 0.0$ & $15.9 \pm 0.1$ & $12.8 \pm 0.0$ & $8.5 \pm 0.0$ & $15.5^{\mathrm{ab}} \pm 0.9$ & $32.0^{a} \pm 0.3$ & $\mathrm{NA}$ \\
\hline Male,1PPI & $72.6^{\mathrm{bc}} \pm 0.6$ & $62.89^{\text {ab }} \pm 0.60$ & $67.7^{\mathrm{abc}} \pm 0.5$ & $69.8^{\mathrm{b}} \pm 0.5$ & $9.2^{b} \pm 0.2$ & $12.74 \pm 0.29$ & $12.9 \pm 0.3$ & $11.5 \pm 0.2$ & $8.4 \pm 0.1$ & $15.4^{\mathrm{bc}} \pm 0.2$ & $26.8^{\mathrm{cd}} \pm 1.0$ & $22.1^{b} \pm 0.3$ \\
\hline Male,2PPI & $75.6^{\mathrm{ab}} \pm 1.9$ & $63.00^{\mathrm{b}} \pm 1.8$ & $68.8 \pm 1^{\text {ab }} .7$ & $71.2^{\mathrm{ab}} \pm 1.6$ & $11.5^{\mathrm{ab}} \pm 0.6$ & $13.08 \pm 0.76$ & $13.7 \pm 0.9$ & $12.7 \pm 0.7$ & $8.7 \pm 0.4$ & $15.3^{\mathrm{bc}} \pm 0.7$ & $29.2^{\mathrm{ab}} \pm 2.7$ & $21.7^{\mp} \pm 0.8$ \\
\hline Male,3PPI & $75.3^{a} \pm 0.2$ & $65.09^{\mathrm{a}} \pm 0.27$ & $69.2^{b} \pm 0.2$ & $71.3^{b} \pm 0.2$ & $9.8^{b} \pm 0.0$ & $3.7 \pm 0.6$ & $15.6 \pm 0.7$ & $13.6 \pm 0.6$ & $9.6 \pm 0.3$ & $16.5^{\mathrm{b}} \pm 0.1$ & $31.0^{a} \pm 2.2$ & $22.8^{\mathrm{b}} \pm 0.6$ \\
\hline Male,4PPI & $77.6^{ \pm} \pm 0.9$ & $67.1^{a} \pm 0.9$ & $72.6^{ \pm} \pm 0.8$ & $74.1^{1} \pm 0.8$ & $12.1^{2} \pm 0.3$ & $16.0 \pm 0.3$ & $16.5 \pm 0.3$ & $13.7 \pm 0.3$ & $10.6 \pm 0.1$ & $16.8^{ \pm} \pm 0.3$ & $35.6^{2} \pm 1.1$ & $23.6^{a} \pm 0.3$ \\
\hline
\end{tabular}

a,b,c,d,e,ab,cd, abc ,bcd means on the same column with different superscripts within the specified dentition group are significantly different $(\mathrm{P}<0.05) ; \mathrm{Ns}=$ Non significant $(\mathrm{P}>0.05)$; *significant at $0.05 ; \mathrm{N} . \mathrm{A}=$ not available, $\mathrm{EL}=$ Ear length; $\mathrm{RH}=$ rump height $\mathrm{CBL}=$ cannon bone length; $\mathrm{RL}=$ Rump length; $\mathrm{RW}=\mathrm{Rump}$ width; $\mathrm{SC}=$ Scrotal circumference; $\mathrm{BL}=$ body length; $\mathrm{CG}=$ chest girth; $\mathrm{HW}=$ height at wither; $\mathrm{BW}=$ body weight; $1 \mathrm{PPI}=$ 1 Pair of Permanent Incisors; 2 PPI = 2Pairs of Permanent Incisors; 3PPI= 3 Pairs of Permanent Incisors; 4PPI = 4 pair of permanent incisors.

\section{Correlation between Body Weight and LBMs}

The Pearson's correlation coefficient between body weight and linear body measurements for male and female are calculated and presented in Table 3 . The presence of strong correlation coefficients recorded between body weight and some of the linear body measurement, suggests that either of these LBMs variables or their combination could provide a good estimate for predicting body weight of indigenous goats in the study area. Body weight had positive and significant $(\mathrm{P}<0.05)$ correlation with all continuous traits of both male and female goats.

In this study, strong, positive and significant correlation between body weight and chest girth suggests that this variable could provide a good estimate in predicting live body weight for the population. In males positive and highly strong association were found between body weight and chest girth $(\mathrm{r}=0.90)$, wither height and body length $(\mathrm{r}=0.87)$, rump height $(\mathrm{r}=0.82)$. Chest depth $(0.70)$. The highest association between chest girth and body weight were observed for male and female goat population. This finding was in agreement with reported by (Grum, 2010; Ahmed, 2013; Alefe., 2014; Alubel, 2015 ,Diba ,2017), correlation between body weight and chest girth for female $(r=0.88)$ and male $(r=0.89)$ short-ear Somali goat; for female $(r=0.89)$ and male $(r=0.81)$ indigenous goats in Horro Guduru Wollega ; for female $(r=0.93)$ and male $(r=0.97)$ for Shabelle Zone,for female $(r=0.76)$ and male $(r=0.84)$ Abergelle goat, and for female $(r=0.97)$ and male $(r=0.98)$ Odo Shakiso and Adola Districts goat ,respectively. These linear body measurements were highly affected by the change in body weight; hence, they are more important in prediction of live body weight of the animal. The rump length $(\mathrm{r}=0.57)$, Ear length $(\mathrm{r}=0.62)$. and pelvic width $(0.50)$ have moderate and positively correlated with body weight. In case of females, body weight had strong correlation with chest girth, whither height, rump height, body length, chest depth with $(\mathrm{r}=0.85),(0.81),(0.80),(0.80),(0.69)$ respectively. And moderately $(0.52)$ and $(0.51)$, respectively the correlation coefficient between body weight and all parameters for males and females in the current study were lower than shabele goats which was reported by Alefe (2014). 
Table 3.Coefficient of correlations between body weight and linear body measurements (Above diagonal for male and below diagonal for female)

\begin{tabular}{|c|c|c|c|c|c|c|c|c|c|c|c|}
\hline & $\mathrm{CG}$ & $\mathrm{BL}$ & WH & HR & $\mathrm{CD}$ & $\mathrm{CBL}$ & $\mathrm{CBC}$ & RW & $\mathrm{HL}$ & BW & $\mathrm{SC}$ \\
\hline $\mathrm{CG}$ & & $0.85^{*}$ & $0.82^{*}$ & $0.81^{*}$ & $0.68 *$ & $0.45^{*}$ & $0.33^{*}$ & $0.48^{*}$ & $0.48^{*}$ & $0.90^{*}$ & $0.58^{*}$ \\
\hline BL & $0.81^{*}$ & & $0.83^{*}$ & $0.82^{*}$ & $0.68^{*}$ & $0.30^{*}$ & $0.40^{*}$ & $0.36^{*}$ & $0.39^{*}$ & $0.87^{*}$ & $0.61^{*}$ \\
\hline WH & $0.83^{*}$ & $0.82^{*}$ & & $0.92^{*}$ & $0.65^{*}$ & $0.22^{\mathrm{NS}}$ & $0.30^{*}$ & $0.29^{*}$ & $0.39^{*}$ & $0.87^{*}$ & $0.59^{*}$ \\
\hline HR & $0.84^{*}$ & $0.81^{*}$ & $0.98^{*}$ & & $0.58^{*}$ & $0.30^{*}$ & $0.35^{*}$ & $0.36^{*}$ & $0.39^{*}$ & $0.82^{*}$ & $0.57^{*}$ \\
\hline $\mathrm{CD}$ & $0.72^{*}$ & $0.66^{*}$ & $0.70^{*}$ & $0.71^{*}$ & & $0.39^{*}$ & $0.40^{*}$ & $0.51^{*}$ & $0.36^{*}$ & $0.70^{*}$ & $0.47^{*}$ \\
\hline CBL & $0.42^{*}$ & $0.48^{*}$ & $0.41^{*}$ & $0.40^{*}$ & $0.37^{*}$ & & $0.23^{\mathrm{NS}}$ & $0.55^{*}$ & $0.45^{*}$ & $0.40^{*}$ & $0.18^{\mathrm{NS}}$ \\
\hline $\mathrm{CBC}$ & $0.39^{*}$ & $0.35^{*}$ & $0.36^{*}$ & $0.37^{*}$ & $0.34^{*}$ & $0.21^{*}$ & & $0.18^{*}$ & $0.42^{*}$ & $0.30^{*}$ & $0.25^{*}$ \\
\hline RW & $0.47^{*}$ & $0.48^{*}$ & $0.50^{*}$ & $0.48^{*}$ & $0.40^{*}$ & $0.30^{*}$ & $0.26^{*}$ & & $0.45^{*}$ & $0.46^{*}$ & $0.37^{*}$ \\
\hline HL & $0.47^{*}$ & $0.44^{*}$ & $0.46^{*}$ & $0.46^{*}$ & $0.43^{*}$ & $0.31^{*}$ & $0.28 *$ & $0.28^{*}$ & & $0.43^{*}$ & $0.35^{*}$ \\
\hline BW & $0.85^{*}$ & $0.80^{*}$ & $0.81^{*}$ & $0.80^{*}$ & $0.69^{*}$ & $0.43^{*}$ & $0.37^{*}$ & $0.48^{*}$ & $0.45^{*}$ & & $0.61^{*}$ \\
\hline
\end{tabular}

$\mathrm{Ns}=$ non-significant $(\mathrm{P}>0.05)$; significant at 0.05 level; $\mathrm{BL}=$ Body Length; $\mathrm{HG}=$ Heart Girth; WH= Wither Height; RH= Rump Height; RW = Rump Width; RL= Rump Length; CD=Chest Depth; PW=Pelvic Width; $\mathrm{SW}=$ Shoulder Width; HL= Head Length; $\mathrm{CBL}=$ Cannon Bone Length; $\mathrm{CBC}=$ Cannon Bone Length; HoL $=\mathrm{Horn}$ Length; EL= Ear Length; BW= Body Weight; $\mathrm{SC}=$ Scrotal Circumference

\section{Prediction of Body Weight from LBMs}

Multiple linear regression models for predicting the body weight of goats from linear body measurements are presented in Table 4. Using measurements obtained readily and offered accurate prediction of body weight might be considered as a framework for recording system in rural areas (Farhad at el., 2013).Regression analysis is commonly used in animal research to describe quantitative relationships between a response variable and one or more explanatory variables such as body weight and body measurements ( chest girth, chest depth, body length and height at wither) especially when there is no access to weighing equipment (Cankaya, 2008 ).

The small sample size of male goat in this study may decrease the accuracy of the result if separate sex groups are used.Comparable $\mathrm{R}^{2}$ values were obtained for all relationships existing between BW and other LBMs for both female and male sample goat population.All body measurements were fitted into the model and through elimination procedures, in this study, the optimum model was identified. Chest girth, body length, height at wither, rump width and rump height were the best fitted model for male goat, whereas chest girth, body length, height at withers, rump height, canon bone circumference and rump width were the best fitted model for female goats.

However, predictions of body weight from combinations of LBMs, having these multiple variables posses a practical problem under field settings due to the higher labor and time needed for measurement. Chest girth selected first, which explain more variation than any other linear body measurements in both does $(71 \%)$ and bucks $(82 \%)$. Chest girth was more reliable in predicting body weight than other linear body measurements at farmers level when there are no facilitates and difficult to measure the weight and to take the whole measurement.Moreover, the adjusted $\mathrm{R}^{2}$ due to additionalvariables in the model was not strong strengthening the preceding argument that heart girth alone could serve as a best predictor of body weight under field condition. Measuring chest girth with tape is easy, cheap and rapid. Thus, body weight prediction from heart girth alone would be a practical option under field conditions.

Thus, prediction of body weight could be based on regression equation $\mathrm{y}=37.93+0.92 \mathrm{x}$ for female sample population and $\mathrm{y}=-44.47+1.02 \mathrm{x}$ for male sample goat populationwhere, $y$ and $x$ are body weight and chest girth, respectively.

In the current study chest girth (CG) was the best predictor variable, which explains more variation than any other linear body measurements in both sexes. This was in agreement with the results of, Grum (2010), Halima et al. (2012), Mahilet (2012),Ahmed (2013), Belete (2013), Biruh (2013), Bekalu(2014) and Hulunim (2014) as heart girth was selected first for prediction of live body weight of animals. 
Table 4. Multiple regression analysis of live weight on different body measurements for male and female goats in the study area

\begin{tabular}{|c|c|c|c|c|c|c|c|c|c|c|c|c|}
\hline \multicolumn{9}{|l|}{ For female goats } & \multirow{3}{*}{$\mathrm{R}^{2}$} & \multirow{3}{*}{$\mathrm{CP}$} & \multirow{3}{*}{$A-R^{2}$} & \multirow{3}{*}{ MSE } \\
\hline Model & \multicolumn{8}{|c|}{ Parameters } & & & & \\
\hline & I & $\beta 1$ & $\beta 2$ & $\beta 3$ & $\beta 4$ & $\beta 5$ & B6 & $\beta 7$ & & & & \\
\hline $\mathrm{CG}$ & -37.93 & 0.92 & & & & & & & 0.71 & 126.07 & 0.71 & 11.56 \\
\hline $\mathrm{CG}+\mathrm{BL}$ & -40.13 & 0.63 & 0.38 & & & & & & 0.75 & 39.95 & 0.04 & 10.24 \\
\hline $\mathrm{CG}+\mathrm{BL}+\mathrm{WH}$ & -44.18 & 0.51 & 0.27 & 0.28 & & & & & 0.76 & 13.19 & 0.01 & 9.63 \\
\hline $\mathrm{CG}+\mathrm{BL}+\mathrm{WH}+\mathrm{CD}$ & -44.53 & 0.47 & 0.26 & 0.26 & 0.16 & & & & 0.76 & 9.44 & 0.002 & 9.62 \\
\hline $\mathrm{CG}+\mathrm{BL}+\mathrm{WH}+\mathrm{HR}+\mathrm{CD}$ & -42.31 & 0.49 & 0.26 & 0.54 & -0.32 & 0.17 & & & 0.76 & 6.89 & 0.002 & 9.61 \\
\hline $\mathrm{CG}+\mathrm{BL}+\mathrm{WH}+\mathrm{HR}+\mathrm{CD}+\mathrm{RW}$ & -42.70 & 0.48 & 0.25 & 0.52 & -0.31 & 0.16 & 0.13 & & 0.78 & 5.85 & 0.001 & 9.61 \\
\hline $\begin{array}{lr}\mathrm{CG}+ & \mathrm{BL}+ \\
\mathrm{HR}+\mathrm{CD}+\mathrm{CBC}+\mathrm{RW}\end{array}$ & -43.55 & 0.48 & 0.25 & 0.53 & -0.32 & 0.16 & 0.24 & 0.12 & 0.79 & 5.74 & 0.001 & 9.60 \\
\hline \multicolumn{13}{|l|}{ For male goats } \\
\hline CG & -44.47 & 1.02 & & & & & & & 0.82 & 31.41 & 0.82 & 6.25 \\
\hline $\mathrm{CG}+\mathrm{WH}$ & -42.21 & 0.65 & 0.36 & & & & & & 0.87 & 9.24 & 0.04 & 4.66 \\
\hline $\mathrm{CG}+\mathrm{BL}+\mathrm{WH}$ & -43.41 & 0.53 & 0.24 & 0.28 & & & & & 0.88 & 6.60 & 0.009 & 4.41 \\
\hline $\mathrm{CG}+\mathrm{BL}+\mathrm{WH}+\mathrm{RW}$ & -43.87 & 0.45 & 0.24 & 0.31 & 0.27 & & & & 0.88 & 5.36 & 0.006 & 4.20 \\
\hline $\mathrm{CG}+\mathrm{BL}+\mathrm{WH}+\mathrm{RW}+\mathrm{RH}$ & -42.70 & 0.45 & 0.27 & 0.45 & -0.20 & 0.32 & & & 0.89 & 4.70 & 0.005 & 4.08 \\
\hline
\end{tabular}

$(\mathrm{I})=$ intercept; $\mathrm{BW}=$ body weight; $\mathrm{BL}=$ body length; $\mathrm{CG}=$ chest girth; $\mathrm{HW}=$ height at withers; $\mathrm{RH}=\mathrm{rump}$ height; $\mathrm{RL}=$ rump width; $\mathrm{CBC}=$ cannon bone circumference $\mathrm{CD}=$ chest depth; $\mathrm{R} 2=\mathrm{R}$ - square; $\mathrm{MSE}=$ Mean square of error; A-R2= adjusted R.2; C (P) = The Mallows C parameters;

\section{Conclusions and Recommendation}

Goats were characterized as having dominantly plain coat color pattern, light red coat color type, smooth hair coat type, short hair length, sloping rump profile. The most dominant ear form carried horizontal. The most frequently observed horn orientation was backward followed by upward.

The least square means for the effect of sex was significant $(\mathrm{p}<0.05)$ on majority quantitative variables except CD, EL, RL and RW. Male goats were higher than females in all variables except ear length. District had significant effect $(\mathrm{p}<0.05)$ on all quantitative variables except horn length and canone bone circumference. Body weight and all LBMs were significantly affected $(\mathrm{p}<0.05)$ by age group.

Positive and significant correlations between LBMs and body weight were observed. Multiple regression equations were developed for predicting live body weight from LBMs. Chest girth was selected first, which explain more variation than any other linear body measurements in both does $(71 \%)$ and bucks $(82 \%)$. The prediction of body weight could be based on regression equation $\mathrm{y}=-37.93+0.92 \mathrm{CG}$ for female sample population and $\mathrm{y}=-44.47+1.02$ CGfor male sample goat population where y is body weight.

One of the main conclusions to be drawn from this study is that Goats in the study area play a significant role for farmers as source of home consumption and income generation throughout the year. In all study area goats have shown inferior performance in body weight and other linear body measurements as compared to the previous carecterztion. the east gojjam goats needs further study to quantify the productive and reproductive performance of the indigenous breeds through monitoring, and also need molecular characterization for deffertate from other breedes.

\section{ACKNOWLEDGEMENT}

I am thankful to God Almighty, the most Gracious and the most Beneficent, who enables me to accomplish this work. I would like to express my gratitude and appreciation to Ministry of Education for fully sponsoring my study and research work.

\section{References}

Abdul waheed,2011).Characterization of goats for linear type traits in Pakistan. A Thesis submitted in partial fulfillment of the requirements for the degree of doctor of philosophy in animal breeding and genetics department of animal breeding and genetics. University of Faisalabad Pakistan. pp193.

Agga, G. E., U. Udala, Regassa, F. Wudie A,2010). Body measurements of bucks of three goat breeds in Ethiopia and their correlation to breed, age and testicular measurements.Small Rumin.Res. 95 (2) :133-138.

Ahmed Seid,2013). On-farm phenotypic and production system characterization of indigenous goats in horro guduru wollega zone.MSc theis. Haramaya University Haramaya, Ethiopia.PP112

Alefe Takele, 2014). Phenotypic characterization of indigenous goat types and their production system in shabelle zone, south eastern Ethiopia. An MSc Thesis, Haramaya University, Haramaya, Ethiopia. 112pp.

Alubel Alemu, 2015). On-farm phenotypic characterizations and performance evaluation of Abergelle and Central highland goat breeds as an input for designing community-based breeding program.MSc theis. Haramaya University Haramaya, Ethiopia.130pp

Arineitwe I and Ndyomugyeni E K ,2013). Boer goat production in Kikatsi Sub County, Kuruhura District, 
Uganda. Livestock Research for Rural Development 25 (6)

Arse Gebeyehu, Feyisa Hundessa, Gurmessa Umeta, Merga Muleta and Girma Debele, 2013). Assessment on challenges and opportunities of goat farming system in Adami Tulu, Arsi Negelle and Fantale districts of Oromia Regional State, Ethiopia. African Journal of Agricultural Research 8(1):26-31.

Assen Ebrahim and Aklilu Haile Michael,2012).Sheep and goat production and utilization in different agroecological zones in Tigray, Ethiopia. Livestock Research For Rural Development 24 (1).

Belay Zeleke and Meseretu Melese,2017).On Farm Phenotypic Characterization Of Indigenous Goat Populations In Gamo Goffa Zone South Western Ethiopia. Journal of Advanced Studies in Agricultural, Biological and Environmental Sciences (JABE). 4(3): 29.

Belete Asefa,2013). On Farm Phenotypic Characterization of Indigenous Goat types and their Production System in Bale Zone of Oromia Region, Ethiopia. MSc. Thesis Presented to the School of Graduate Studies of Haramaya University, Haramaya. Pp116.

Biruh Tesfahun,2013). Phenotypic and production system characterization of Woyto Guji Goats in Lowland areas of South Omo Zone an MSc Thesis, Haramaya University, Haramaya, Ethiopia. 89pp.

Cam, M. A, Olfaz, M. Soydan, E,2010). Possibilities of using morphmetric characteristics as a tool for body weight prediction in Turkish hair goats (Kilkeci). Asian Journal of Animal and Veterinary Advances, 5 (1): $52-59$.

Cochran, W. G,1977).Sampling techniques, 3rd edition. New York: John Wiley and Sons.

CSA (central statistics agency), 2017. Agricultural sample survey: VO .II. Report on livestock and livestock characteristics. Stastatistical Bulletin 570. CSA Addis Abeba Ethiopia.

Damitie Kebede, Alemash Melese, Kefyalew Alemayehu, Shigdaf Mekuriaw, Sileshi Andualem(2015). Indigenous goat production systems in selected districts of Western Amhara, Ethiopia. Journal of Harmonized Reasearch in Applied Sciences.3 (4):186.

Dejen Assefa, 2010. Phenotypic characterization of indigenous sheep types in Keffa and Bench- Maji Zone of Southern Ethiopia. An MSc Thesis Presented to School of Graduate Studies of Haramaya University, Ethiopia. 25-35p.

Dereje, T, 2011. Herd husbandry and breeding practices of goat in different agro-ecologies of Western Hararghe, Ethiopia. MSc thesis. Jimma, Ethiopia: Jimma University.

Dereje, T., Mengistu, U., Getachew, A, and Yoseph, M, 2015. A review on productive and reproductive characteristics of indigenous goats in Ethiopia. Livestock Research for Rural Development 27 (2).

Deribe, B. and M. Taye, 2014. Reproductive Performance of Abergelle Goats Raised under Traditional Management Systems in Sekota District, Ethiopia. Ira. J. 60 of Apl. Ans. 4(1):59-63.

Dhaba Urgessa, Belay Duguma, Solomon Demeke and Taye Tolamariam,2012a.Sheep and Goat Production Systems in Ilu Abba Bora Zone of Oromia Regional State, Ethiopia: Feeding and Management Strategies Global Veterinaries 9 (4):421-429

Diba Dedacha,2017. Phenotypic characterization of indigenous goat type, breeding and husbandry practices in odo shakiso and adola districts. MSc thesis, Submitted to the School of Graduate Studies of Haramaya University, Ethiopia. Pp 136.

Dinka Hunduma, Tigre Worku, Wagari Moti and Regassa Feyesa,2010. Preliminary Study on Major Health Problems of the Newly Introduced Boer Goat Breed in Ethiopia World Applied Sciences Journal 11 (7):803-807.

Endeshaw Assefa, Girma Abebe, Azage Tegegne, Yosef T / Georgis and Berhanu G / medhin ,2011. Goat Production System and Opportunities for Market Orientation in Southern Ethiopia.

FAO (food and agricultural organization), 2011. Draft guidelines on phenotypic characterization of animal genetic resources. Commission on genetic resources for food and agriculture, thirteenth regular session.

FAO (food and agricultural organization), 2012. Phenotypic characterization of animal geneticresources.FAO Animal Production and Health Guidelines No.11. Rome

Farhad Hosseinzadeh, Shirzeyli Abolghasem and Lavvaf Asad Asadi., 2013.Estimation of Body Weight from Body Measurements in Four Breeds of Iranian Sheep.

FARM-Africa(1996). Types of Ethiopia and Eritrea. Physical description and management systems. Published jointly by FARM-Africa, London, UK and International Livestock ResearchInstitute, Nairobi, Kenya.

Feki Misbah,2013. Community-based characterization of Afar goat breeds around Aysaita district of Afar region. MSc thesis. Jimma, Ethiopia: Jimma University.

Feki Misbah, Berhanu Belay and Aynalem Haile,2015. Participatory definition of trait preference and pastorals' indigenous knowledge on goat breeding strategy around Aysaita district, Ethiopia.Livestock Research for Rural Development 27 (8).

Ferra, J.C., S.Cieslak, R.S. Filho, C.McManus, C.L. Martins, J.R.B. Sereno,2010. Weight and age at puberty and their correlations with morph metric measurements in crossbreed breed Suffolk ewe lambs. Revista Brasileira de Zootecnia 39: 134-141 
Funk, Rowland, Eilerts, Kebebe E, Biru et al ,2012. Climate trend analysis of Ethiopia. Climatelchange adaptation series.U.S. Geological survey famine early warning systems Network-Informing (FEWSNET) Fact sheet 3053: 6 .

Getinet M,2016. Molecular characterization of Ethiopian indigenous goat Populations: genetic diversity and structure, demographic Dynamics and assessment of the kisspeptin gene polymorphism Degree of Doctor of Philosophy in Applied Genetics Addis Ababa University

Gidado, O. G., Kibon A., Gwargwor Z. A., Mbaya P \& Baba M.J,2013. Assessment of anti-nutritive factors and nutrient composition of some selected browse plants used as livestock feeds in Taraba State. International Journal of Applied Science and Enginering. 1 (1):5-9.

Girma Debele, Misgana Duguma and Feyisa Hundessa,2011. Effect of Different Factors on Mortality Rate of Arsi- Bale Kids in Mid Rift Valley of Ethiopia. Global Veterinaries 6 (1):56-60

Girma Debele, Misgana Duguma, Feyisa Hundessa, Firhowet Messele, Tesfaye Kebede and Mohammed Negash,2013. Study on major causes of kid mortality in Adami Tulu Jido Kombolcha District of Oromia, Ethiopia. Agriculture and Biology Journal of North America.

Grum Gebreyesus,2010. Community-Based Participatory Characterization of the Short Eared Somali Goat Population around Dire Dawa .MSc thesis, Submitted to the School of Graduate Studies of Haramaya University, Ethiopia 129p.

Gurmessa Umeta, Feyisa Hundesa, Misgana Duguma and Merga Muleta,2011a. Analysis of goat production situation at Arsi Negele Woreda, Ethiopia.Journal of Stored Products and Postharvest Research 2(8):156 163.

Halima H, Samer L, Barbara R, Michael B and Markos T,2012. Molecular characterization of Ethiopian indigenous goat populations. Tropical Animal Health and Production, 44 (6):1239-1246.

Hulunm Gatew,2014. On-farm phenotypic characterization and performance evaluation of Bati, Borena and Short eared Somali goat populations of Ethiopia. MSc theis. Haramaya University Haramaya, Ethiopia. Addis Ababa Ethiopia.pp15

Hussein Hassen Toyib,2015. Phenotypic characterization and breeding practices of Arsi-Bale goat population in selected districs of Arsi and Bale zones, Oromia regional state, Ethiopia. MScthesis. Bahir Dar University, Bahir Dar, Ethiopia.

Kebede.T. A. Haile and H. Dadi, 2011. Goat Breeding and Flock Management Practices in the Central Rift Valley of Ethiopia. Adami Tulu Agricultural Research Center, P.O. Box 35, Zeway, Ethiopia.Trop Anim Health Prod, 44(5):999-1006.

Mahilet Dawit,2012. Characterization of Haraghe Highland Goat and Their Production System in Eastern Haraghe. An MSc Thesis Haramaya University, Haramaya. , Ethiopia

Netsanet Zergaw,2014. On-farm phenotypic characterization and performance evaluation of Central highland and Woyto-Guji goat breeds for designing community based breeding program in Ethiopia. MSc. Thesis.Haramaya University, Haramaya, Pp147.

Nigatu Dejene,2017.Assessment of Production and Marketing Systems, and On-Farm Evaluation of The Effect of Supplementing The Leaves of Balanites Aegyptiaca and Maize Grain on Growth Performance and Economic Return of Indigenous Goats in Gamogofa zone. M.Sc. Thesis, HawassaUniversity. Hawassa, Ethiopia. 132pp.

Okbeku, M, M., Yakubu, A., Olusolapeters, S., Ozoje, M.O., Ikeobi, C.O., Adebambo, O.A. andImumorin, I.G,2011. Application of multivariate principal component analysis to morphological characterization of indigenous goats in southern Nigeria.

Shumuye Belay, Gebreselassie Gebru, Guesh Godifey, Minister Brhane, Mulalem Zenebe, Hailay Hagos and Tsegay Teame,2014. Reproductive performance of Abergelle goats and growth rate of their crosses with Boer goats.Livestock Research for Rural Development, Volume 26.

Solomon Abegaz,2014. Design of community based breeding programs for two indigenous goat breeds of Ethiopia. Doctoral Dissertation, January 2014 Vienna, Austria.

Solomon Gizaw, Azage Tegegne, Berhanu Gebremedhin and Dirk Hoekstra,2010.Sheep and goat production and marketing systems in Ethiopia: Characteristics and strategies for improvement. IPMS (Improving Productivity and Market Success) of Ethiopian Farmers Project Working Paper 23. ILRI (International Livestock Research Institute), Nairobi, Kenya. 58p.

SPSS (Statistical Package for Social Sciences). 2011. SPSS (Statistical Package for Social Sciences) release version 20, SPSS Inc.

Tasssew Mohammed,2012. On-Farm Phenotypic Characterization of Native Sheep Types and Their Husbandry Practices in North Wollo Zone of the Amhara Region. Msc Thesis Presented to School of Graduate Studies, Haramaya University Ethiopia. 120p.

Tatek Woldu, Markemanna A, Reiber C, Philipp C M and Valle Zárate A,2016. Optimizing contributions of goat farming to household economic success and food security in three production systems in Ethiopia. Journal 
of Agriculture and Rural Development in the Tropics and Subtropics, 117: 73-85

Tegegne Fantahun,2012. On-farm phenotypic characterization of goat genetic resources in Bench Maji zone, southwestern Ethiopia.MSc thesis. Bahir Dar, Ethiopia: Bahir Dar University.

Tesfaye Kebede, Aynalem Haile, Hailu Dadi, 2011. Smallholder goat breeding and flock management practices in the central rift valley of Ethiopia. Trop.anim healthy and prod.44:999-1006.

Teshome Abate, Abule Ebro and Lisanework Nigatu,2010. Traditional rangeland resource utilization practices and pastoralists perceptions on land degradation in southeast Ethiopia.Tropical grass lands. 44: 202-212.

Tsigabu Gebreselassie,2015. Phenotypic characterization of goat type and their husbandry practices in Nuer zone of Gambella people regional state, south western Ethiopia. MSc thesis Haramaya University.

Yaekob Lorato,2014. Community Based Characterization of Woyto Guji goat in Loma district, SNNP. Accept regional State of Ethiopia Accept for award of M.sc (Animal Breeding and Genetics), Jimma university, Jimma, Ethiopia. 142.

Yisehak Kechero, Taye Tolamariam and Aynalem Haile,2013. Characteristics and Determinants of Livestock Production in Jimma Zone/Southwestern Ethiopia. Afri. J. Bas. \& Ap.Sci.5 (2): 69-81. 